\title{
EFEK PAPARAN SUBKRONIK DEBU VULKANIK GUNUNG KELUD TERHADAP KADAR KOLESTEROL TOTAL TIKUS JANTAN MODEL DIABETES MELITUS
}

\author{
Elly Mayangsari ${ }^{\star \bowtie}$, I Putu Adi Santosa**, Gauca Syadzaiffat Chikita ${ }^{* * *}$
}

\begin{abstract}
Abstrak
Penduduk disekitar Gunung Kelud yang memiliki riwayat diabetes mellitus berisiko menghirup debu vulkanik yang bisa menyebabkan stres oksidatif melalui terbentuknya radikal bebas. Pada penderita diabetes melitus, keadaan hiperglikemia memicu terbentuknya radikal bebas. radikal bebas yang terbentuk karena kondisi hiperglikemia dan pengaruh paparan debu vulkanik ini menyebabkan kerusakan pada membran sel hepar dan meningkatkan kolesterol total darah. Penelitian ini bertujuan untuk membuktikan bahwa pemaparan debu vulkanik Gunung Kelud mempengaruhi peningkatan kadar kolesterol total pada tikus Wistar model diabetes melitus. studi eksperimental menggunakan post-test only control group design dilakukan pada 25 ekor tikus Wistar jantan. Sampel dibagi ke dalam 5 kelompok, yaitu kelompok kontrol negatif, kelompok kontrol positif, kelompok perlakuan 1, kelompok perlakuan 2, dan kelompok perlakuan 3. Variabel yang diukur adalah kadar kolesterol total. Hasil penelitian menunjukkan bahwa kenaikan kadar kolesterol total tikus setelah dipapar debu vulkanik berbeda bermakna $(p=0,049 ; a=0,05)$. Terdapat hubungan yang kuat antara dosis paparan debu vulkanik dengan kadar kolesterol total serum tikus jantan Rattus norvegicus galur Wistar model diabetes mellitus $(p=0,016, r=0,609)$. Kesimpulan dari penelitian ini adalah paparan debu vulkanik Gunung Kelud dapat meningkatkan kadar kolesterol total tikus putih model diabetes melitus.
\end{abstract}

Kata Kunci: debu vulkanik, diabetes melitus, kolesterol total.

\section{SUBCHRONIC EXPOSURE EFFECT OF KELUD VOLCANIC ASH TO TOTAL CHOLESTEROL LEVELS IN DIABETES MELLITUS RAT MODEL}

\begin{abstract}
Communities around Mount Kelud who have a history of diabetes mellitus at risk of inhaling volcanic dust that can cause oxidative stress through the formation of free radicals. In patients with diabetes mellitus, hyperglycemia leads to the formation of free radicals. Free radicals formed due to the conditions of hyperglycemia and the effect of exposure to volcanic ash is causing damage to the hepatic cell membrane and increases total blood cholesterol. This study aimed was to prove that exposure to volcanic ash of mount Kelud affect total cholesterol levels in the Wistar rat model of diabetes mellitus. Experimental studies using post-test only control group design performed on 25 male Wistar rats. Samples were divided into five groups, i.e. negative control group, positive control group, treatment group 1, treatment group 2, and treatment group 3. The variables measured were total cholesterol. The results showed that the increase in total cholesterol of rat after being exposed to volcanic ash was significantly different $(p=0.049 ; a=0.05)$. There was a strong relationship between the exposure dose of volcanic ash on the blood serum total cholesterol level $(p=0.016$, $r=0.609$ ). The conclusion of this study is volcanic ash of mount Kelud increase total cholesterol in diabetes mellitus rats.
\end{abstract}

Keywords: volcanic dust, diabetes mellitus, total cholesterol

* Departemen Farmakologi, Fakultas Kedokteran, Universitas Brawijaya

${ }^{* *}$ Departemen Patologi Klinik, Fakultas Kedokteran, Universitas Brawijaya - RSUD. Dr. Saiful Anwar Malang

***Program Studi Pendidikan Dokter Fakultas Kedokteran Universitas Brawijaya

${ }^{凶}$ E-mail: mayangga1605@gmail.com 


\section{Pendahuluan}

Gunung Kelud, dengan tinggi puncak 1,731 termasuk salah satu gunung aktif di Indonesia. Secara geografis, terletak di $7056^{\prime}$ LS dan 112 18' 30" BT. Gunung Kelud terletak di 3 kota di Jawa Timur sekaligus yaitu Kediri, Blitar, dan Malang. ${ }^{1}$ Pada tanggal 13 Februari 2014, Gunung Kelud meletus dan salah satu material yang dihasilkan yaitu debu vulkanik atau pasir vulkanik yang disemburkan ke udara saat terjadi letusan. Lima komposisi tertinggi pada debu vulkanik gunung berapi adalah silicon dioksida $55 \%$, besi oksida $18 \%$, aluminium oksida $18 \%$, kalsium oksida $8 \%$, dan magnesium oksida 2,5\%. ${ }^{2}$ Jumlah penduduk sekitar Gunung Kelud yang terpapar debu vulkanik sekitar 201.228 jiwa. Sebagian penduduk Gunung Kelud memiliki riwayat diabetes melitus, sehingga berisiko menghirup debu vulkanik dan menimbulkan stres oksidatif yang memicu terbentuknya radikal bebas. ${ }^{3}$

Radikal bebas merupakan sekelompok atom yang tidak memiliki elektron pada lapisan terluarnya. ${ }^{4}$ Radikal bebas terdiri dari reactive oxygen species (ROS), reactive nitrogen species (RNS), dan senyawa radikal lainnya. ROS meliputi oxygen free radicals (OFRS) atau oksigen radikal seperti anion superoksida $(\mathrm{O} 2 \cdot-)$, radikal hidroksil $(\mathrm{OH} \cdot)$, radikal peroksil (ROO•), hydrogen peroksida $(\mathrm{H} 2 \mathrm{O} 2)$, dan oksigen singlet (O2). ${ }^{5}$

Diabetes melitus (DM) adalah gangguan metabolik yang heterogen, bisa disebabkan oleh kelainan genetik dan secara klinik dengan gejala rendahnya kemampuan toleransi terhadap karbohidrat. ${ }^{6}$ Pada DM terdapat ketidakmampuan reaksi kimia untuk memanfaatkan karbohidrat, lemak, dan protein dari makanan karena ketidakcukupan atau ketidakefektifan hormon insulin yang diproduksi oleh tubuh. Pada DM terjadi peningkatan glukosa darah secara kronis.
Kadar glukosa darah (GD) bervariasi dalam beberapa kondisi seperti: GD puasa, yaitu normal, bila GD kurang dari $110 \mathrm{mg} / \mathrm{dl}$, toleransi glukosa terganggu (TGT), bila GD 110-126 mg/dL, diabetes mellitus, bila GD lebih dari $126 \mathrm{mg} / \mathrm{dL}$. Kadar glukosa 2 jam setelah mengkonsumsi 75 gram glukosa, yaitu TGT, bila GD 140-200 mg/dL, diabetes melitus bila GD lebih dari $200 \mathrm{mg} / \mathrm{dL}^{7}$ Meningkatnya kadar glukosa darah atau hiperglikemia pada penderita DM dapat menyebabkan terbentuknya radikal bebas dan kolesterol. ${ }^{8}$

Pada penderita diabetes sering terjadi hiperkolesterolemia dan hiperlipidemia karena peningkatan lipolisis jaringan adipose dan menstimulasi terjadinya fatty liver. ${ }^{9}$ Ditambah lagi dengan terjadinya apoptosis sel endotel dan radikal bebas yang menyebabkan disfungsi endotel. ${ }^{10}$

Kolesterol adalah lemak hasil sintesis asetil Koa. Asetil KoA yang sudah membentuk HMG CoA dipecah oleh HMG CoA reduktase menjadi mevalonate menggunakan ekuivalen pereduksi NADPH. Aktifitas enzim pereduksi HMG CoA dipengaruhi oleh hormon insulin, glukagon, tiroid, dan glukokortikoid. Peningkatan hormon glucagon menyebabkan enzim pereduksi HMG CoA terfosforilasi dan menjadi inaktif, begitu juga sebaliknya dengan hormon insulin. 8,11

Patomekanisme yang mendasari kelainan vaskuler pada individu diabetes melitus yang terpapar debu vulkanik diduga didasari oleh stres oksidatif, meskipun belum ada penelitian yang mengkaji hubungan tersebut. Oleh karena itu, studi ini bertujuan untuk mengevaluasi pengaruh paparan debu vulkanik Gunung Kelud terhadap peningkatan kadar kolesterol total pada tikus model diabetes melitus.

\section{Bahan dan Metode}


Penelitian ini merupakan penelitian eksperimental in vivo pada tikus Wistar jantan (Rattus norvegicus) model DM dengan post test only control group design. Sampel penelitian menggunakan 25 ekor tikus Wistar jantan dewasa yang berumur sekitar 3 bulan, dengan berat badan 100-250 gram, dan dalam kondisi sehat. Sampel dibagi dalam lima kelompok secara random sampling, yaitu kelompok tikus normal (kontrol negatif), kelompok tikus diabetes melitus (kontrol positif), kelompok tikus diabetes melitus yang diberi paparan debu vulkanik dosis 6.25 $\mathrm{mg} / \mathrm{m}^{3} 1$ jam/hari selama 28 hari (perlakuan 1), Kelompok tikus diabetes melitus yang diberi paparan debu vulkanik dosis 12.5 $\mathrm{mg} / \mathrm{m}^{3} 1$ jam/hari selama 28 hari (perlakuan 2), kelompok tikus diabetes melitus yang diberi paparan debu vulkanik dosis $25 \mathrm{mg} / \mathrm{m}^{3}$ 1 jam/hari selama 28 hari (perlakuan 3). Penelitian ini telah disetujui oleh Komisi Etik Fakultas Kedokteran Universitas Lambung Mangkurat Banjarmasin dengan Keterangan Kelaikan Etik No. 022/KEPK-FK UNLAM/EC/VIII/2012.

Alat yang digunakan dalam penelitian ini yaitu spuit injeksi intraperitoneal, kandang, botol minum, timbangan, alat pemapar debu vulkanik, ependorf, mikropipet, alat sentrifugasi, spektrofotometer. Bahan yang digunakan adalah streptozotocin (STZ) dengan dosis $55 \mathrm{mg} / \mathrm{KgBB}$ sebagai induksi hiperglikemi, pakan normal standar tikus dengan komposisi yaitu protein, minyak dan selulosa, air minum, serta debu vulkanik sebagai bahan perlakuan.

Perlakuan pada masing-masing kelompok dilakukan selama 28 hari sebagai periode waktu subkronik. Pemaparan debu vulkanik dalam penelitian ini dilakukan setiap hari dengan durasi satu jam. Pemaparan debu vulkanik berlangsung selama periode subkronik atau 28 hari. Setelah perlakuan, tikus dimatikan sesuai ethical clearance, dan semua kelompok tikus diambil sampel darah dari jantung, kemudian disentrifus untuk mendapatkan serum darah yang akan dianalisis kadar kolesterol total dengan menggunakan metode CHOD-PAP (cholesterol oxidase phenol 4-aminoantipyrine peroxidase).

Data yang diperoleh diolah menggunakan program SPSS 17.0 menggunakan uji one-way ANOVA. Apabila terdapat perbedaan yang bermakna maka dilakukan uji post-hoc Tukey untuk melihat seberapa besar perbedaan tiap kelompok perlakuan dengan tingkat kepercayaan $95 \%$ (bila nilai $p<0,05$ ) dan dilakukan uji korelasi Pearson untuk mengetahui apakah dosis paparan debu vulkanik berpengaruh terhadap kadar kolesterol total.

\section{Hasil}

Hasil analisis statistik dengan
menggunakan uji one-way ANOVA menunjukkan bahwa paparan debu vulkanik secara subkronik pada kelompok perlakuan berpengaruh secara signifikan terhadap kadar kolesterol total serumpada tikus model DM, dengan nilai signifikansi $p=0,049(p<0,05)$ (Gambar 1). 


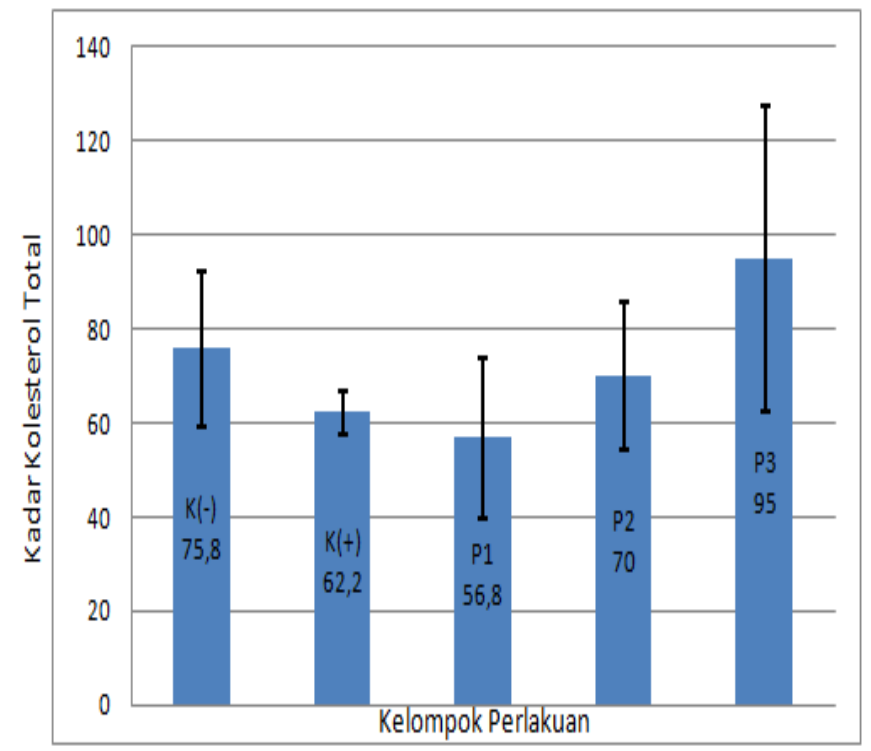

Gambar 1. Rata-rata kadar kolesterol total ( $\left.\mathrm{mg} / \mathrm{m}^{3}\right)$ pada masing-masing kelompok. Keterangan: $\mathrm{K}(-)$ kontrol negatif, $\mathrm{K}(+)$ kontrol positif, (P1) induksi STZ + paparan debu vulkanik dosis $6,25 \mathrm{mg} / \mathrm{m}^{3}$, (P2) induksi STZ + paparan debu vulkanik dosis $12,5 \mathrm{mg} / \mathrm{m}^{3},(\mathrm{P} 3)$ induksi $\mathrm{STZ}+$ paparan debu vulkanik dosis

$25 \mathrm{mg} / \mathrm{m}^{3}$.

\section{Pembahasan}

Hasil penelitian (Gambar 1) menunjukkan rata-rata kadar kolesterol total untuk kelompok P1 adalah $56,8 \pm 17,181$ $\mathrm{mg} / \mathrm{m}^{3}, \mathrm{P} 2$ adalah $70 \pm 15,604 \mathrm{mg} / \mathrm{m}^{3}$, dan P3 adalah $95 \pm 32,504 \mathrm{mg} / \mathrm{m}^{3}$. Dari hasil tersebut dapat dikatakan bahwa terdapat kenaikan kadar kolesterol total serum tikus yang disebabkan oleh pemberian dosis paparan debu vulkanik yang berbeda tiap kelompok perlakuan. Adapun dosis paparan debu vulkanik yang diberikan pada kelompok $\mathrm{P} 1$ adalah $6,25 \mathrm{mg} / \mathrm{m}^{3}, \mathrm{P} 2=12,5 \mathrm{mg} / \mathrm{m}^{3}$, dan kelompok $\mathrm{P} 3=25 \mathrm{mg} / \mathrm{m}^{3}$.

Berdasarkan penelitian yang dilakukan oleh Sholihah dan Widodo (2008), di dalam debu batubara terdapat silika yang memicu terbentuknya ROS. Hal ini terjadi secara pasif mekanik melalui proses produksi pemecahan partikel batubara dan secara aktif melalui reaksi inflamasi biologis. ROS yang terbentuk dalam tubuh manusia umumnya terjadi akibat respons imunitas humoral. Mekanisme ini sebagai reaksi munculnya inflamasi yang diakibatkan induksi partikel debu batubara.
Reaksi sistem imun terhadap inflamasi ROS umumnya terjadi pelepasan sitokin IL-1, IL-6, IL-8, dan TNF. Partikel penginduksi pembentukan ROS umumnya berukuran 1,510 mikrometer. Partikel yang berukuran lebih dari 2,5 mikrometer dapat memicu aktifitas makrofag alveolar, sedangkan partikel yang lebih halus mampu menginduksi inflamasi di daerah alveolar, sehingga silika dalam debu vulkanik akan menginduksi terjadinya ROS dan berdampak pada peningkatan kolesterol total. ${ }^{12}$

Pada Gambar 1 didapatkan penurunan kadar kolesterol total serum tikus pada kelompok P1 (DM dan paparan debu dosis $6.25 \mathrm{mg} / \mathrm{m}^{3}$ ) yaitu $56,8 \pm 17,181 \mathrm{mg} / \mathrm{m}^{3}$ dibandingkan dengan kelompok $\mathrm{K}(+)$ yaitu $62,2 \pm 4,817 \mathrm{mg} / \mathrm{m}^{3}$. Pada kelompok K(-) yaitu $75,8 \pm 16,634 \mathrm{mg} / \mathrm{m}^{3}$ memiliki rata-rata kadar kolesterol total yang lebih tinggi dari kelompok P1 yaitu $56,8 \pm 17,181 \mathrm{mg} / \mathrm{m}^{3}$ dan kelompok P2 yaitu70 $\pm 15,604 \mathrm{mg} / \mathrm{m}^{3}$. Kelompok $\mathrm{K}(+)$ yaitu $62,2 \pm 4,817 \mathrm{mg} / \mathrm{m}^{3}$ dibandingkan kelompok kontrol negatif $\mathrm{K}(-)$ $75,8 \pm 16,634 \mathrm{mg} / \mathrm{m}^{3}$ menunjukkan adanya penurunan kadar kolesterol total kelompok 
$\mathrm{K}(+)$ dibandingkan kelompok $\mathrm{K}(-)$. Hal ini disebabkan oleh beberapa faktor antara lain adanya aktivitas fisik yang berbeda dari masing-masing tikus. Berdasarkan penelitian Rahmawati dkk. (2009), aktifitas fisik yang tinggi memberikan dampak pada rasio kolesterol total/HDL yang baik. Faktor lain yang diduga berpengaruh terhadap hasil yang didapat adalah hormonal, aktivitas enzim cholesteryl ester transfer protein (CETP), dan aktivitas enzim lipoprotein lipase (LPL) otot. Hal ini karena dalam penelitian ini hanya mengukur kadar kolesterol total tikus dalam darah. ${ }^{13}$ Pada penelitian ini, pengukuran kadar kolesterol total sebelum pemaparan tidak disamakan.

Peningkatan kadar kolesterol total serum terjadi pada kelompok P2 (DM dan paparan debu dosis $12.5 \mathrm{mg} / \mathrm{m}^{3}$ ) dan kelompok P3 (DM + paparan debu dosis $25 \mathrm{mg} / \mathrm{m}^{3}$ ) dibandingkan dengan kelompok $\mathrm{K}(+)$. Peningkatan kadar kolesterol total serum juga terjadi pada kelompok P3 dibandingkan dengan kelompok K(-). Hal ini sesuai dengan teori bahwa keadaan hiperglikemia pada pasien DM dapat memicu pembentukan radikal bebas dan kolesterol. ${ }^{8}$ Diabetes juga mampu meningkatkan lipolisis jaringan adiposa dan menstimulasi terjadinya hiperlipidemia dan fatty liver, sehingga pada pasien DM juga menyebabkan terjadi hiperkolesterolemia dan hiperlipidemia serta apoptosis sel endotel oleh ROS yang mengakibatkan disfungsi endotel.9,10 Pada kelompok P2 dan P3 yang dipapar dengan debu vulkanik menambah kemungkinan untuk terjadinya peningkatan kadar kolesterol total dengan terjadinya stres oksidatif. Hasil analisis data post hoc test Tukey HSD terdapat perbedaan signifikan kadar kolesterol total antara kelompok P1 dan P3 $(p=0,40)$. Namun, di antara masing-masing kelompok perlakuan dengan kelompok kontrol tidak memiliki perbedaan yang bermakna. Hal ini disebabkan oleh dosis paparan debu vulkanik yang diberikan pada kedua kelompok berbeda yaitu dosis $6,25 \mathrm{mg} / \mathrm{m}^{3}$ pada P1 dan dosis $25 \mathrm{mg} / \mathrm{m}^{3}$ padaP3. Dari dosis di atas dapat diketahui bahwa paparan pada kelompok P3 mengandung kristal silika yang lebih tinggi dibandingkan paparan pada kelompok P1, sehingga bisa meningkatkan kadar kolesterol total serum dalam periode waktu subkronik.

Pada hasil uji korelasi, yang digunakan untuk mengetahui kekuatan hubungan antara peningkatan dosis paparan debu vulkanik dengan kadar total kolesterol serum, didapatkan nilai $p=0,016(p<0,05)$ yang memiliki arti signifikan, linier, dan $\mathrm{H}_{0}$ ditolak. Nilai $r=+0,609$ yang memiliki arti hubungan searah $(+)$ dan hubungan kuat $(r=0,50$ $0,75)$.

\section{Kesimpulan}

Paparan debu vulkanik dapat meningkatkan kadar kolesterol total tikus Wistar model diabetes melitus. Semakin tinggi dosis debu vulkanik, semakin tinggi kadar kolesterol total. Hubungan terkuat terdapat pada paparan debu vulkanik dosis $25 \mathrm{mg} / \mathrm{m}^{3}$.

\section{Saran}

Penelitian selanjutnya dapat mengeksplorasi lama paparan debu vulkanik pada semua dosis untuk mengetahui adanya pengaruh terhadap kadar kolesterol total.

\section{Daftar Pustaka}

1. Jannah TPNM\& Fauzy A. Interval Konfidensi Bagi Fungsi Tahan Hidup. 2015. P. 174-180.

2. Suryani AS. Dampak Negatif Abu Vulkanik terhadap Lingkungan dan Kesehatan.2014; VI(04):9-12.

3. BBC. Gunung Kelud Meletus, Hujan Abu Hingga Wilayah Jateng. (Online). 2014.http://www.bbc.com/indonesia/berit 
a_indonesia/2014/02/140214_gunung_k elud meletus. Diakses 16 November 2015.

4. Arief S. Radikal Bebas. Surabaya:IImu Kesehatan Anak FK UNAIR/RSU Dr. Soetomo. 2007. P. 1-9.

5. Puspitasari ML, WulansariTV, Widyaningsih TD, \& Mahar J. Aktivitas Antioksidan Suplemen Herbal Daun Sirsak (Annona muricata L) dan Kulit Manggis (Garcinia mangostana L). 2016;4(1):283-290.

6. Josten S. Profil Lipid Penderita Diabetes Mellitus Tipe 2.Indonesian Journal of Clinical Pathology and Medical Laboratory. 2006; 13(1):20-22.

7. Dewi K. Peranan Pengobatan dengan Akupuntur pada Diabetes Mellitus dalam Era Globalisasi. Zenit. 2012; 1(2):73-81.

8. Murray RK, Granner DK, Mayes PA,dan Rodwell VW. Biokimia Harper. Hartono A (Penerjemah). Jakarta: EGC.2003.

9. Hardman JG, Limberd LE. Insulin, Oral Hypoglycemic Agents and the
Pharmacology of the Endocrine Pancreas. In:Goodman and Gilman's the Pharmacological Basis of Therapeutics. $11^{\text {th }}$ edition. USA:McGraw-Hill Company Limited. 2001.1383-1399.

10. Mohora M, Virgolici B, Paveliu F, Lixandru D, Muscurel C, Greabu M. Free Radical Activity in Obese Patients with Type 2 Diabetes Mellitus. Rom J Intern Med.2006;1:69-78.

11. Harvey RA and Ferrier DR.Biochemistry. Philadelphia: Lippincott Williams \& Wikins.2011.

12. Sholihah QM dan Widodo $A$. Pembentukan Radikal Bebas Akibat Gangguan Ritme Sirkadian dan Paparan Debu Batubara. Jurnal Kesehatan Lingkungan . 2008; 4(2): 89-100.

13. Lira FS et al. Low and Moderate, Rather Than High Intensity Strength Exercise Induces Benefit Regarding Plasma Lipid Profile. Diabetology and Metabolic Syndrome Journal. 2010; 2(31):1-6. 